\title{
A Report of Late Blight of Potato Caused by Phytophthora Infestans in Gilgit-Baltistan (GB) Pakistan
}

\author{
Aqleem Abbas ${ }^{1 *}$ \\ ${ }^{1}$ Department of Plant Pathology, The University of Agriculture, Pakistan
}

Submission: December 18, 2017; Published: February 02, 2018

*Corresponding author: Aqleem Abbas, Department of Plant Pathology, The University of Agriculture, Pakistan; Email: aqlpath@gmail.com

\section{Introduction}

Potato (Solanum tuberosum L.) is the most widely grown food crop in the world having high nutritional and economical value. It produces more calories per hectare as compared to cereals such as rice and wheat $[1,2]$. It is one of the member of Solanacea family which also included chilli, eggplant, tobacco and tomato [3]. Though it has originated in the Andes region and from there it reached to subcontinent by Portuguese traders. Now it has become an integral part of almost every dish in Pakistan. Pakistan having unique weather is suitable for the production of potato [4]. Recently the production of potato has increased in Gilgit Baltistan (GB) Pakistan due to increased acreage as well as due to the introduction of new cultivars in this area. Potato is a cash crop so it has become major source of income for the farmers. The production of potato crop in 2017 was approximately 20 bags (Each bag was of $70-80 \mathrm{Kg}$ ) per Kanal area. However to estimate total annual potato production of GB is difficult to do accurately due to the fact that the region is highly mountainous and crop mature at different dates depending on the altitudes of potato growing areas. Since the disease resistant traditional varieties of plants have been replaced by high yielding but susceptible varieties. As a result major threats come in the form of various diseases. Among these diseases late blight is the most important one affecting potatoes $[5,6]$. The causal agent of the late bight is Phytophthora infestans (Mont.) de Bary, which is not only limiting the production of potatoes in GB but also worldwide [7]. Currently in GB it is the most destructive disease of because of its increasing distribution potential. The potato cultivars were introduced to GB from the Kalam and Malam Jaba valleys of Swat district of Pakistan in 1990s. Ever since late blight has been found from all the the potato growing areas of GB notably in the elevated valleys such as Nalter, Nomal and Dayetar Valleys. GB has a cooler climate so the climate is favorable to pathogen. However the pathogen has potential to adapt a diverse range of environmental conditions. The disease has devastating effects on potato tubers (Figure 1) as well as foliage.

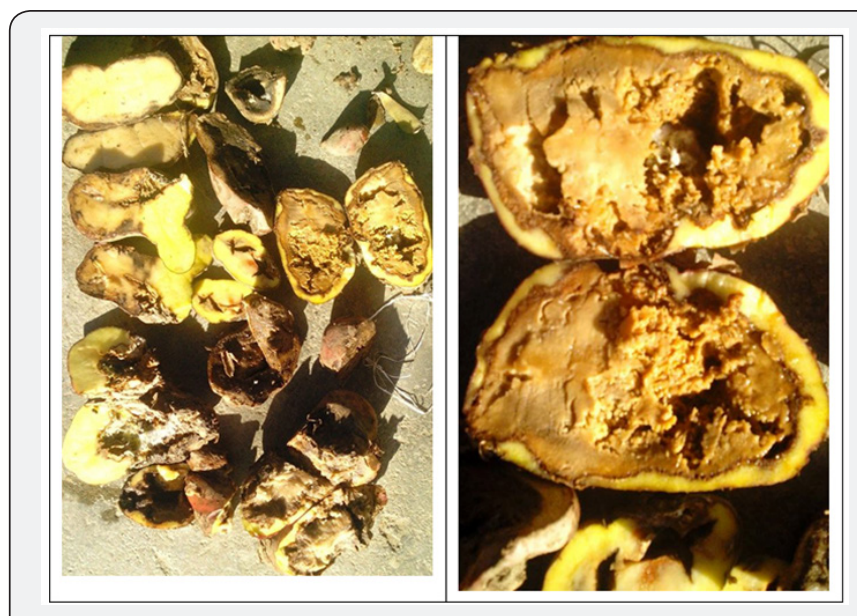

Figure 1: Potato tubers infected with late blight disease.

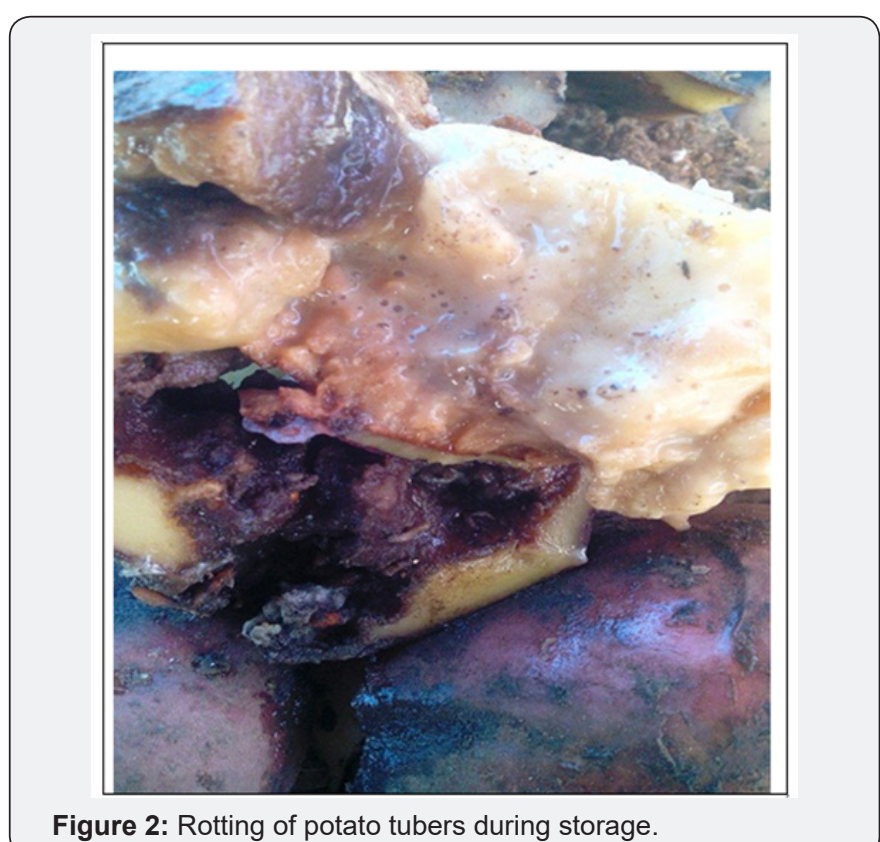


The temperate as well as other climatic conditions [8] of GB are favorable for the rapid multiplication of this diseases. The recent erratic and hugh rainfall have also contributed in the increment of this disease. The pathogen is found to infecting all stages potato crop stems along with the tubers and leaves are also found to be infected. Whitish cottony growth on the lower side of foliage and on the edges of the leaves. Brownish green lesions are fond on the uppers side of foliage. However the dark brown or black lesions were observed on the petioles and stems. Potato tubers were found to be rotting (Figure 2).

\section{Management}

Late blight of potato can be controlled by the integrated disease management (IDM) strategy [9]. The ideal way to combat this disease is through the development of resistant cultivars. However, there is not any such Plant Breeding and Plant Pathology institute in GB for the screening of potato germplasm against late blight of potato. Currently every commercial variety is susceptible to late blight disease. In other provinces of Pakistan new varieties have been developed however need to be test for the presence of resistance genes to late blight disease. Fungicides may play an important role in reducing the incidence of late blight however in GB the farmers have no access to fungicides. Moreover the application of fungicides may reduce the local diversity of other organisms as well as pollute the environment.

\section{Acknowledgement}

The research was partially funded by Higher Education Commission (HEC) of Pakistan on Fee Reimbursement Scheme for PhD student.

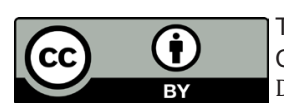

This work is licensed under Creative Commons Attribution 4.0 Licens DOI: 10.19080/IJCSMB.2018.04.555627

\section{References}

1. Poehlm JM, Slepper DA (1995) Breeding Field Crops. ( $4^{\text {th }}$ edn). Lowa State Univ. Press/ Ames, USA, pp. 419-433.

2. Hylla SA, Gostner, Dusel G (1998) Effects of resistant starch on the colon in healthy volunteers: possible implications for cancer prevention. Am J Clin Nutr 67(1): 136-142.

3. Hijmans RJ, Spooner DM (2001) Geographic distribution of wild potato species. Am J Bot 88(11): 2101-2112.

4. Anonymous (2017) Agricultural Statistics of Pakistan. Govt. of Pakistan. Ministry of Food, Agriculture, and Livestock. Food, Agriculture \& Livestock Division (Economic Wing), Islamabad.

5. Agrios GN (2005) Plant Pathology. (5 $5^{\text {th }}$ edn), Academic Press, New York, USA, pp. 106-107.

6. Ahmad I, JI Mirza (1995) Occurrence of $\mathrm{A}^{2}$ mating type of Phytophthora infestans in Pakistan. Nat Sem on Res \& Dev of Potato Prod. In Pakistan p. 23-25.

7. Younis M, Khan MA, Sahi ST, Ahmad R (2009) Genotypic variations among different potato lines/varieties for tolerance against late blight disease. Pak J Phytopathol 21(1): 13-17.

8. Tosun N, Yildirim A, Turkusay H, Tanyolac B (2007) Genetic variation among Phytophthora infestans (tomato blight) isolates from western turkey revealed by inter simple sequence repeat (issr) and random amplified polymorphic dna (rapd) markers. Pak J Bot 39(3): 897-902.

9. Parvez ES, Hussain A, Rashid, Ahmad MZ (2003) Evaluation of different protectant and eradicant fungicides against early and late blight of potato caused by A solani (Eliss and Mart) Jones and Grouht and Phytophthora infestans (Mont.) De Barry under field conditions. Pak J Biol Sci 6(23): 1942-1944.

\section{Your next submission with Juniper Publishers will reach you the below assets}

- Quality Editorial service

- Swift Peer Review

- Reprints availability

- E-prints Service

- Manuscript Podcast for convenient understanding

- Global attainment for your research

- Manuscript accessibility in different formats ( Pdf, E-pub, Full Text, Audio)

- Unceasing customer service

Track the below URL for one-step submission https://juniperpublishers.com/online-submission.php 